\title{
Dış Ortam Sıcaklıkları ve Güneş Işınımı Şiddeti Dikkate Alınarak Adana İli İçin Optimum Yalıtım Kalınlığı Tespiti
}

\author{
Meral ÖZEL ${ }^{1 *}$, Sefa KUNT ${ }^{2}$ \\ 1,2 Makine Mühendisliği, Mühendislik Fakültesi, Fırat Üniversitesi, Elazı̆̆, Türkiye \\ ${ }^{* 1}$ mozel@ firat.edu.tr, ${ }^{2}$ sefakunt1@ @mail.com
}

\begin{abstract}
Öz: Bu çalışmada, Türkiye'nin en sıcak şehirlerinden biri olan Adana ili için ısıtma ve soğutma yükleri esas alınarak bina dış duvarlarının optimum yalıtım kalınlığı belirlenmiştir. İlk olarak Adana ilinin dış ortam sıcaklıkları ve güneş ışınımı şiddeti dikkate alınarak ısıtma ve soğutma derece-gün değerleri hesaplanmıştır. Daha sonra ise binanın 10 yıllık ömrü üzerinden enerji tüketim maliyetini içine alan bir maliyet analizine göre optimum yalıtım kalınlıkları iki farklı yalıtım malzemesi için belirlenmiştir. Sonuç olarak, sadece diş ortam sıcaklığı göz önünde bulundurulduğunda 1sıtma ve soğutma derece gün değerlerinin sırasıyla $838^{\circ} \mathrm{C}$.gün ve $315{ }^{\circ} \mathrm{C}$.gün olarak elde edildiği, güneş ışınımının da dikkate alınması durumunda bu değerlerin $753^{\circ} \mathrm{C}$.gün ve $410^{\circ} \mathrm{C}$.gün olarak elde edildiği görülmüştür. Ayrıca, güneş 1şınımının etkisiyle optimum yalıtım kalınlıklarının EPS ve XPS yalıtım malzemeleri için sırasıyla 8.0 ve $4.8 \mathrm{~cm}$ olarak elde edildiği görülmüştür.
\end{abstract}

Anahtar kelimeler: Dış ortam sıcaklığı, Güneş ışınımı, Isıtma ve Soğutma Derece-gün değerleri, Optimum yalıtım kalınlığı.

\section{Determination of Optimum Insulation Thickness for Adana City by Considering Outdoor Temperature and Solar Radiation Intensity}

\begin{abstract}
In this study, optimum insulation thickness of the building external walls for Adana city which is one of the hottest cities of Turkey is determined based on heating and cooling loads. Firstly, heating and cooling degree-day values are calculated by taking into consideration the outdoor temperatures and solar radiation intensity of Adana city. Then, the optimum insulation thicknesses are determined according to a cost analysis that included the energy consumption cost over the 10 years of the building for two different insulation materials. As result, it is seen that the heating and cooling degree day values are obtained as $753^{\circ} \mathrm{C}$.day and $410^{\circ} \mathrm{C}$.day by considering both outdoor temperature and solar radiation while they are obtained as $838^{\circ} \mathrm{C}$.day and $315{ }^{\circ} \mathrm{C}$.day by considering only outdoor temperature. Furthermore, it is seen that optimum insulation thicknesses with the effect of solar radiation are obtained to be 8.0 and $4.8 \mathrm{~cm}$ for EPS and XPS insulation materials, respectively.
\end{abstract}

Key words: Outdoor temperature, Solar radiation, Heating and cooling Degree-Day values, Optimum insulation thickness.

\section{Giriş}

Ülkemizdeki enerji üretimi, tüketilen enerjinin büyük bir çoğunluğunu karşılayamadığından çoğunlukla ithal edilmektedir. Nüfus artışı, kentleşme, büyük şehre göç ve yaşam standartlarının gelişmesi ile enerji tüketimi hızla artmaktadır [1]. Enerji tüketimi; sanayi, bina, ulaştırma ve tarım gibi dört ana sektör arasında dağılım göstermektedir. Sanayi sektöründen sonra en geniş enerji tüketimine sahip olan sektör bina sektörüdür. Ülkemizde konut ve yapı sektörünün, toplam enerjinin yaklaşık yüzde 30-35' ini tüketmesi ve büyük bir tasarruf potansiyeline sahip olması, bu sektöre yönelik ilgiyi artırmıştır. Bu yüzden, kış aylarında 1sı kayıplarını yaz aylarında da 1s1 kazançlarını azaltmak için en etkin yol bina dış kabuk elemanlarının yalıtılmasıdır [2].

Bina dış duvarlarına uygulanan yalıtım kalınlığı seçilirken, 1Sı geçiş yüklerindeki azalmanın yanı sıra yalıtımın maliyeti de dikkate alınmalıdır. Bu durumda yalıtım kalınlığının optimum değeri maliyet analizi yapılarak belirlenmelidir. Bu konuyla ilgili yapılan çalışmalar incelendiğinde; Yıldız vd., yapılarda 1S1 yalıtım kalınlığının ekonomik ve çevresel analizini derece-gün metodunu kullanarak yapmışlardır [3]. Kaynaklı, Bursa' daki binaların dış duvarları için 1992' den 2005' e kadar dış hava sıcaklık değerleri dikkate alınarak ısıtma mevsimi için derece-saat değerleri hesaplanmış ve optimum yalıtım kalınlığı belirlenmiştir [4]. Özel ve Şengür, üç farklı yalıtım malzemesi ve üç farklı yakıt türü için Antalya ve Kars illerinin optimum yalıtım kalınlıklarını, enerji tasarruflarını ve geri ödeme sürelerini sadece 1sıtma, sadece soğutma ve hem 1sıtma hem de soğutma derece-gün sayıları göz önüne alınarak ayrı ayrı hesaplamışlardır [5]. Çomaklı ve Yüksel, Erzurum, Kars ve Erzincan gibi Türkiye'nin en soğuk üç şehri için optimum yalıtım kalınlığını derece gün sayılarını esas alarak araştırmışlar [6].

\footnotetext{
* Sorumlu yazar: mozel@ firat.edu.tr. Yazarın ORCID Numarası: ${ }^{1}$ 0000-0002-9516-4715
} 
Gölcü vd., Denizli’ deki binalarda, ısıtma için farklı enerji kaynaklarının kullanılması halinde dış duvarlar için optimum yalıtım kalınlığını Derece-Gün sayısını esas alarak hesaplamışlar [7]. Hasan, duvarların optimum kalınlığını bulmak için ömür maliyet analizini ve derece gün fikrini kullanmıştır. Sonuç olarak duvar yapısının tiplerine bağlı olarak geri ödeme periyodunun polistiren yalıtımı için 1 ile 1.7 yılları arasında değiştiğini ve taş yünü yalıtımı için ise 1.3 ile 2.3 yılları arasında değiştiğini göstermiştir [8]. Bolattürk, Isparta bölgesindeki binaların duvar ve çatı döşemeleri için optimum yalıtım kalınlıkları ve enerji tasarruflarını araştırmıştır. Bunun için yine Derece-Gün sayısı esas alınmıştır [9]. Bolattürk' ün başka bir çalışmasında, Türkiyenin 4 iklim bölgesinden seçilen 16 şehir için ısıtma derece-gün fikrini kullanarak optimum yalıtım kalınlıkları ve geri ödeme süreleri hesaplanmıştır [10]. Dombaycı vd., iki farklı yalıtım malzemesi ve beş farklı enerji kaynağı için derecegün değerlerini kullanarak dış duvarların optimum yalıtım kalınlığını bulmuşlardır [11]. Bolattürk, yıllık 1sıtma ve soğutma yüklerine göre derece-saat metodunu kullanarak optimum yalıtım kalınlığı, enerji korunumu ve geri ödeme süresini belirlemiştir [12]. Yu vd., güneş 1şınımının etkisini göz önünde bulundurarak 1sıtma ve soğutma derece-gün değerlerine göre optimum yalıtım kalınlığını belirlemişlerdir [13]. Al-Khawaja, sıcak ülkelerdeki binalara 1Sı akışını azaltmak için kullanılan bazı yalıtım malzemelerinin optimum kalınlığını araştırmıştır [14]. Daouas, Tunus ikliminde farklı duvar yönlendirmelerine göre optimum yalıtım kalınlığını hesaplamak için bir analitik metot kullanmıştır [15]. Al-Sanea vd., Riyad'ın iklim şartlarını kullanarak kararlı periyodik şartlarda boşluklu duvarlar için optimum yalıtım kalınlığını belirlemişlerdir [16]. Aynı yazarların bir diğer çalışmalarında dinamik 1sı transfer modeli kullanılarak bina duvarlarındaki optimum yalıtım kalınlığı üzerine elektrik tarifesinin etkisi araştırılmıştır [17]. Ozel ve Pıhtılı, ısıtma ve soğutma derece gün değerlerini kullanarak beş farklı il için optimum yalıtım kalınlıklarını belirlemişlerdir [18]. Kaynaklı vd., güneş 1şınımını dikkate alarak Farklı yönlere bakan bina dış duvarları için gerekli yalıtım kalınlıklarının değişimini incelemişlerdir [19]. Yamankaradeniz ve Kaynaklı, 4. bölge derece gün il grubunda yer alan örnek bir il için yıllık dış hava sıcaklık verilerinden yararlanarak derece-gün sayısını tespit ederek 1sıtma sezonunun başlama ve bitiş tarihlerini belirlemişlerdir. Daha sonra ise optimum yalıtım kalınlıklarını farklı derece-gün sayıları, duvar tipleri ve yalıtım malzemeleri için tespit etmişlerdir [20]. Bolattürk, binaların dış duvarlarındaki optimum yalıtım kalınlığı yıllık 1sıtma ve soğutma yüklerine dayandırılarak analiz edilmiştir. Bunun için yıllık ısıtma ve soğutma derece saatleri hesaplanarak, ekonomik model P1-P2 metoduna göre belirlenmiştir [21]. Dağıdır ve Bolattürk, İzmir ili için güneş radyasyonlu ve radyasyonsuz ısıtma ve soğutma yüklerini kullanarak optimum yalıtım kalınlıkları, enerji tasarrufları ve geri ödeme sürelerini belirlemişlerdir. Hesaplamalarda 1sıtma derecesaat sayıları için $18^{\circ} \mathrm{C}$, soğutma derece-saat sayıları için ise $26^{\circ} \mathrm{C}$ denge sıcaklığı kullanmışlardır [1]. Özel ve Tunç, Türkiye'nin en soğuk şehirlerinden biri olan Kars ilinin ilk önce 1sıtma yükleri derece-gün ve derece-saat olarak ve güneş ışınımı değerleri de dikkate alınarak belirlenmiş daha sonra ise bina dış duvarlarının optimum yalıtım kalınlığı belirlenmiştir [22].

Bu çalışmada ise, Türkiye'nin en sıcak şehirlerinden biri olan Adana ili için 1sıtma ve soğutma yükleri dış ortam sıcaklıkları ve güneş ışınımı şiddeti dikkate alınarak belirlenmiş daha sonra ise elde edilen 1sıtma ve soğutma derece-gün değerleri optimum yalıtım kalınlığı hesabı için kullanılmıştır.

\section{Adana İli İçin Isıtma ve Soğutma Periyotlarının Tespiti}

Bu çalışmada Adana ilinin Isıtma ve soğutma periyotları, dış ortam sıcaklıkları ve güneş 1şınımı şiddeti dikkate alınarak aşağıdaki gibi iki yöntemle belirlenmiştir.

Yöntem 1: Bu yöntemde Isıtma ve Soğutma Derece-Gün değerleri sadece dış ortam sıcaklığı dikkate alınarak aşağıdaki gibi hesaplanır:

$$
\begin{aligned}
& I D G=\sum_{1}^{N}\left(T_{i}-T_{o}\right)^{+} \\
& S D G=\sum_{1}^{N}\left(T_{o}-T_{i}\right)^{+}
\end{aligned}
$$

Burada $T_{i}$ denge sıcaklığı, $T_{o}$ günlük ortalama dış ortam sıcaklığı ve $\mathrm{N}$ 1sıtma yapılan toplam gün sayısıdır. Parantezin üzerindeki + işareti ise sadece pozitif değerlerin hesaba katılacağını göstermektedir.

Yöntem 2: Bu yöntemde ise Isıtma ve Soğutma Derece-Gün değerleri, dış ortam sicaklığg ve güneş 1şınım şiddeti birlikte göz önüne alınarak aşağıdaki gibi hesaplanabilir:

$$
I D G=\sum_{1}^{N}\left(T_{i}-T_{e}\right)^{+}
$$


$S D G=\sum_{1}^{N}\left(T_{e}-T_{i}\right)^{+}$

$\mathrm{T}_{\mathrm{e}}$ eşdeğer çevre sıcaklığı olarak adlandırılır ve dış ortam sıcaklığı ile güneş ışınımı şiddetini birlikte ifade edebilen ve gün boyunca periyodik bir değişim gösteren bir teorik sıcaklık olup dik duvar yüzeyleri için aşağıdaki bağıntı yardımıyla hesaplanmaktadır [23]:

$T_{e}(t)=T_{o}(t)+\frac{\alpha \cdot I(t)}{h_{o}}$

Burada $T_{o}$ dış ortam sıcaklığı ve $\alpha$ dış yüzeyin güneş 1şınımını yutma oranı olup 0.6 alınmıştır. $h_{o}$ değeri dış ortamın taşınım katsayısı olup $22 \mathrm{~W} / \mathrm{m}^{2} \mathrm{~K}$ alınmıştır. I ise güneş 1 şınım şiddeti olup meteorolojiden temin edilmiştir.

\section{Dış Duvarların Isı Kazanç ve Kaybı}

Binalardaki 1sı kazanç ve kayıpları genel olarak dış duvarlardan, pencerelerden, tavan ve döşemeler ile hava infiltrasyonu sonucu gerçekleşmektedir. Ancak bu çalışmada sadece diş duvarlarda oluşan ısı kazanç ve kayıpları göz önüne alınarak optimum yalıtım kalınlığı hesaplanmıştır. Bu durumda soğutma ve ısıtma derece-gün sayılarına bağlı olarak birim yüzeyden gerçekleşen yıllık ısı kazanç ve kaybı aşağıdaki gibidir:

$q_{A, S}=86400 \cdot U \cdot S D G$

$q_{A, I}=86400 \cdot U \cdot I D G$

Burada U duvarın toplam ısı transfer katsayısı olup aşağıdaki gibi hesaplanabilir:

$U=1 /\left(R_{w t}+x_{y} / k_{y}\right)$

$R_{w t}=R_{i}+R_{w}+R_{o}$

Burada $R_{i}$ ve $R_{o}$ iç ve dış ortamın ısıl dirençleri, $R_{w}$ yalıtımsız duvar tabakalarının ısıl direncidir. Duvar dış ve iç yüzeyinde $2 \mathrm{~cm}$ lik sıva $(\mathrm{k}=0.72 \mathrm{~W} / \mathrm{mK}), 20 \mathrm{~cm}$ kalınlığında tuğla $(\mathrm{k}=0.62 \mathrm{~W} / \mathrm{mK})$ ve yalıtım malzemesinden oluşmaktadır. Duvarın iç ve dış yüzeyindeki ısı transfer katsayısı sırasıyla 6 ve $22 \mathrm{~W} / \mathrm{m}^{2} \mathrm{~K}$ olarak alınmış ve $\mathrm{R}_{\mathrm{wt}}=0.5903 \mathrm{~m}^{2} \mathrm{~K} / \mathrm{W}$ olarak elde edilmiştir. Yalıtım malzemesi olarak EPS ve XPS kullanılmıştır.

\section{Optimum Yalıtım Kalını ı̆ı İçin Maliyet Analizi}

Binaların dış duvarlarına yalıtım uygulanarak ısı kazanç ve kaybı önemli ölçüde azaltılmış olur. Yalıtımın optimum kalınlığı, binanın ömrü üzerinden enerji tüketim maliyeti ve yalıtım maliyetini içine alan toplam maliyetin minimum olduğu değerdir. Bu durumda, 1sıtma ve soğutma için yıllık enerji maliyeti aşağıdaki gibidir:

$$
\begin{aligned}
C_{A, I} & =\frac{q_{A, I} \cdot C_{f}}{H_{u} \cdot \eta} \\
C_{A, S} & =\frac{q_{A, S} \cdot C_{e}}{3,6 \times 10^{6} \cdot C O P}
\end{aligned}
$$

Burada, $C_{f}, C_{e}, H_{u}$ ve $\eta$ ise sırasıyla yakıt fiyatı (TL/kg), elektriğin fiyatı (TL/kWh), yakıtın alt 1 sıl değeri (J/kg) ve ısıtma sisteminin verimidir. Bu durumda yalıtılmış bir binanın toplam maliyeti aşağıdaki bağıntı yardımıyla hesaplanmaktadır.

$C_{t}=\left(C_{A, I}+C_{A, S}\right) \cdot P W F+C_{y} \cdot x$ 
Burada $C_{y}$ ve $x$ sırasıyla, yalımın fiyatı $\left(\mathrm{TL} / \mathrm{m}^{3}\right)$ ve kalınlığıdır. Optimum yalıtım kalınlı̆̆ı belirlenirken, $\mathrm{N}$ yıllık ömür üzerinden toplam 1sıtma maliyeti şimdiki değer faktörü $(P W F$ ) ile birlikte değerlendirilmelidir. $P W F$, faiz oranı (i) ve enflasyon oranı (g)' ye bağlı olarak aşağıdaki şekilde hesaplanır.

$$
P W F=\frac{(1+r)^{N}-1}{r(1+r)^{N}}, \quad\left\{\begin{array}{ll}
i>g & r=\frac{i-g}{1+g} \\
i<g & r=\frac{g-i}{1+i}
\end{array}\right\}
$$

Toplam maliyeti minimum yapacak yalıtım kalınlığı bize optimum yalıtım kalınlığını vermektedir. Buna göre optimum yalıtım kalınlığı, toplam maliyeti veren (9) nolu denklemin yalıtım kalınlığına (x) göre türevi alınarak aşağıdaki gibi elde edilir

$$
x_{o p}=293,94 \sqrt{\frac{k_{y} \cdot P W F}{C_{y}}\left(\frac{I D G \cdot C_{f}}{H_{u} \cdot \eta}+\frac{S D G \cdot C_{e}}{3,6 \times 10^{6} \cdot C O P}\right)}-k_{y} \cdot R_{w t}
$$

Maliyet hesaplamalarında kullanılan parametreler Tablo 1' de verilmiştir.

\begin{tabular}{|c|c|}
\hline Parametre & Değeri \\
\hline $\begin{array}{l}\text { Isttma: Doğal Gaz } \\
\text { Fiyatı } \\
\mathrm{H}_{\mathrm{u}} \\
\eta \\
\text { Soğutma: Elektrik } \\
\text { Fiyat1 } \\
\text { COP }\end{array}$ & $\begin{array}{l}1.174 \mathrm{TL} / \mathrm{m}^{3} \\
34.525 * 10^{6} \mathrm{~J} / \mathrm{m}^{3} \\
\% 93 \\
0.434 \mathrm{TL} / \mathrm{kWh} \\
2.5\end{array}$ \\
\hline $\begin{array}{l}\text { Yalıtım: XPS } \\
\mathrm{k} \\
\text { Fiyatı } \\
\text { Yalıtım: EPS } \\
\mathrm{k} \\
\text { Fiyatı } \\
\mathrm{R}_{\mathrm{wt}}\end{array}$ & $\begin{array}{l}0.029 \mathrm{~W} / \mathrm{mK} \\
252 \mathrm{TL} / \mathrm{m}^{3} \\
\\
0.036 \mathrm{~W} / \mathrm{mK} \\
140 \mathrm{TL} / \mathrm{m}^{3} \\
0.5903 \mathrm{~m}^{2} \mathrm{~K} / \mathrm{W}\end{array}$ \\
\hline Faiz oran1, (i) & $\% 9.75$ \\
\hline \begin{tabular}{|l|} 
Enflasyon oran1, $(\mathrm{g})$ \\
\end{tabular} & $\% 8.53$ \\
\hline $\mathrm{N}$ & $10 \mathrm{y} 11$ \\
\hline
\end{tabular}

Tablo 1. Hesaplamalarda kullanılan parametreler [24, 25].

\section{Sonuçlar ve Değerlendirme}

Bu çalışmada, Türkiye'nin en sıcak şehirlerinden biri olan Adana ilinin ısıtma ve soğutma yükleri esas alınarak bina dış duvarlarında kullanılan yalıtımın optimum kalınlığının belirlenmesi amaçlanmıştır. Bu amaç için, ilk önce Adana ilinin 1sıtma ve soğutma periyotları, meteorolojiden alınan dış ortam sıcaklığı ve güneşlenme şiddeti verileri dikkate alınarak iki yöntemle belirlenmiştir. Birinci yöntemde sadece dış ortam sıcaklıkları ikinci yöntemde ise güneş ışınımı şiddetinin de dikkate alındığı eşdeğer çevre sıcaklıkları kullanılmak suretiyle 1sıtma ve soğutma periyotları belirlenmiştir. Daha sonra ise elde edilen 1sıtma ve soğutma derece-gün değerlerine bağlı olarak optimum yalıtım kalınlıkları iki farklı yalıtım malzemesi için (EPS ve XPS) hesaplanmıştır. Literatürdeki çoğu çalışmada güneş 1şııımı şiddeti göz önünde bulundurulmadan sadece dış ortam sıcaklık verilerine göre ve sadece ısıtma derece gün değerleri dikkate alınarak optimum yalıtım kalınlıkları belirlenmiştir. Güneş ışınımının dikkate alındığı eşdeğer çevre sıcaklıklarına göre 1sıtma ve soğutma derece gün değerlerinin hesaplanması ve buna 
göre optimum yalıtım kalınlıklarının belirlenmesi daha gerçek sonuçlar elde etmemizi sağlar. Bu yüzden bu çalışmada bu durumlar dikkate alınarak gerekli çözümler yapılmıştır.

Adana ilinin diş hava sıcaklıklarının yıl boyunca değişimi 18 ve $26{ }^{\circ} \mathrm{C}$ denge sıcaklıkları için sırasıyla Şekil 1 ve 3' de görülmektedir. Şekil 2 ve 4 ise Adana ilinin sadece dış ortam sıcaklıklarına göre belirlenen sırasıyla 1sıtma ve soğutma derece gün değerlerinin yıl boyunca değişimini göstermektedir. Şekil 1'den görüldüğü gibi 18 ${ }^{\circ} \mathrm{C}$ denge sıcaklığı için ısıtma sezonunun başlangıç ve bitiş noktaları eğrinin kesim noktaları olup, sırasıyla yılın 91. (1 Nisan) ve 308. (4 Kasım) günleridir. Yani Adana ili için ısıtma periyodu 4 Kasımda başlar ve 1 Nisan tarihinde sona erer. $26^{\circ} \mathrm{C}$ denge sıcaklığı için soğutma sezonunun başlangıç ve bitiş noktaları ise yine eğrinin kesim noktaları olup, sırasıyla yılın 165. (14 Haziran) ve 270. (27 Eylül) günlerine karşılık geldiği Şekil 3'de görülmektedir. Bu durumda soğutma periyodu ise 14 Haziranda başlayıp 27 Eylülde sona ermiştir. Isıtma ve soğutmanın yapılmadığı günlerde Isıtma derece gün ve soğutma derece gün değerlerinin sıfır olduğu Şekil 2 ve 4'de görülmektedir. Her gün için bulunan Isıtma ve Soğutma Derece Gün değerleri ayrı ayrı toplandığında $\mathrm{IDG}=838^{\circ} \mathrm{C}$.gün ve $\mathrm{SDG}=315^{\circ} \mathrm{C}$.gün olarak hesaplanmıştır.

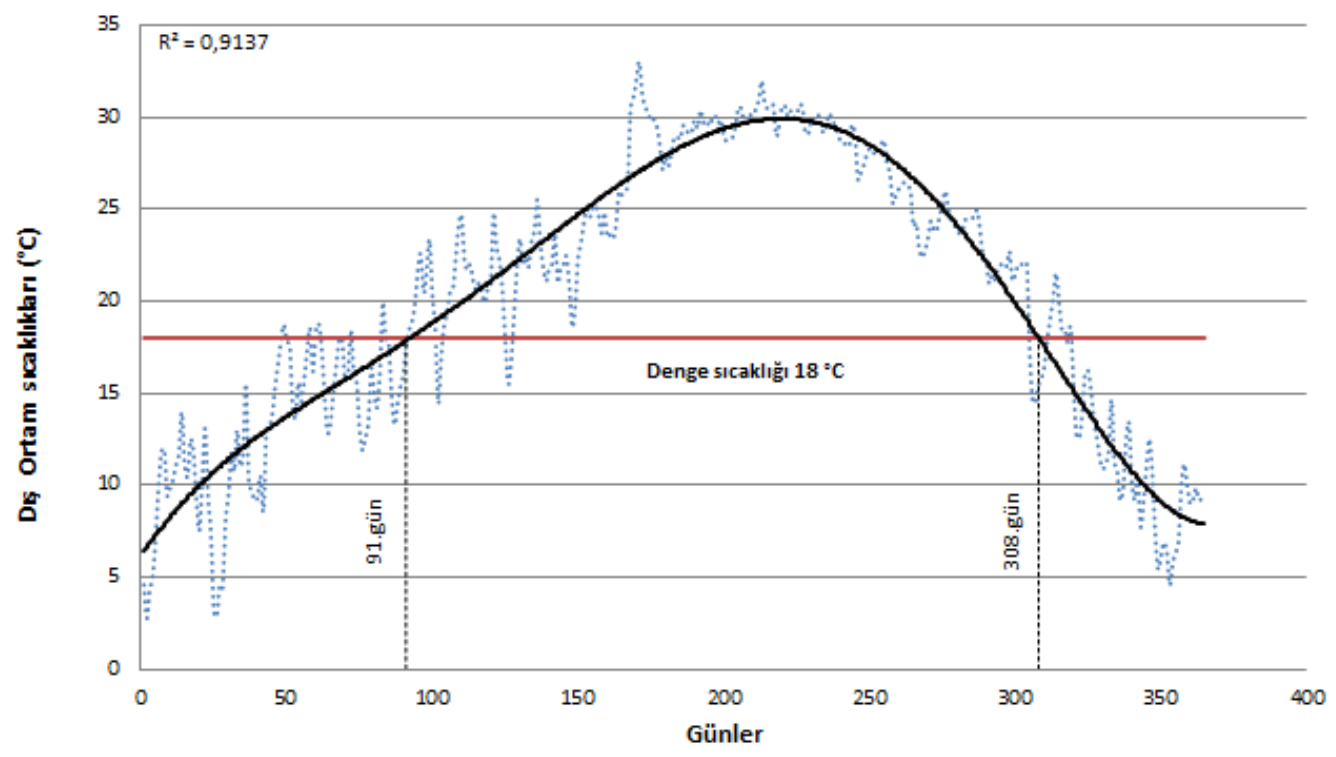

Şekil 1. Adana ili için dış hava sıcaklığının yıl boyunca günlük değişimi $\left(\mathrm{T}_{\mathrm{i}}=18^{\circ} \mathrm{C}\right)$

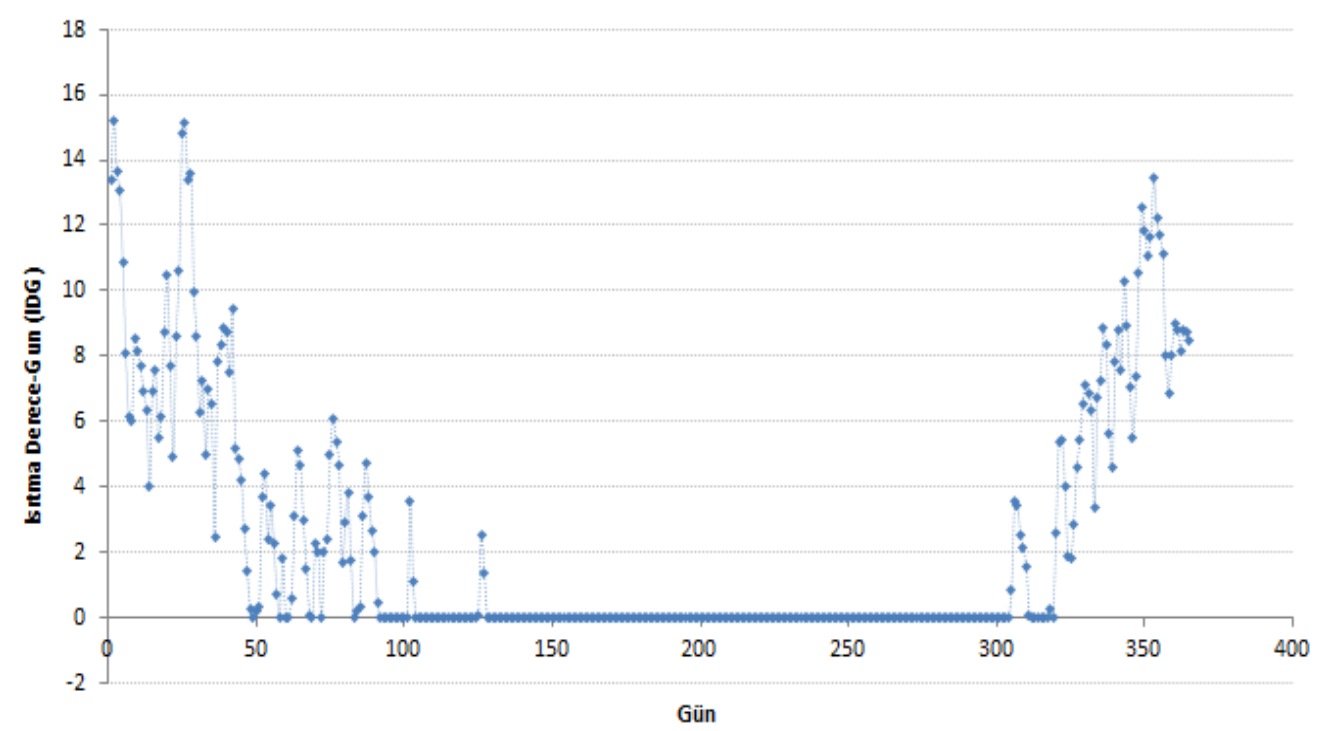

Şekil 2. Dış ortam sıcaklıklarına göre Isıtma Derece-Gün (IDG) değerlerinin değişimi 


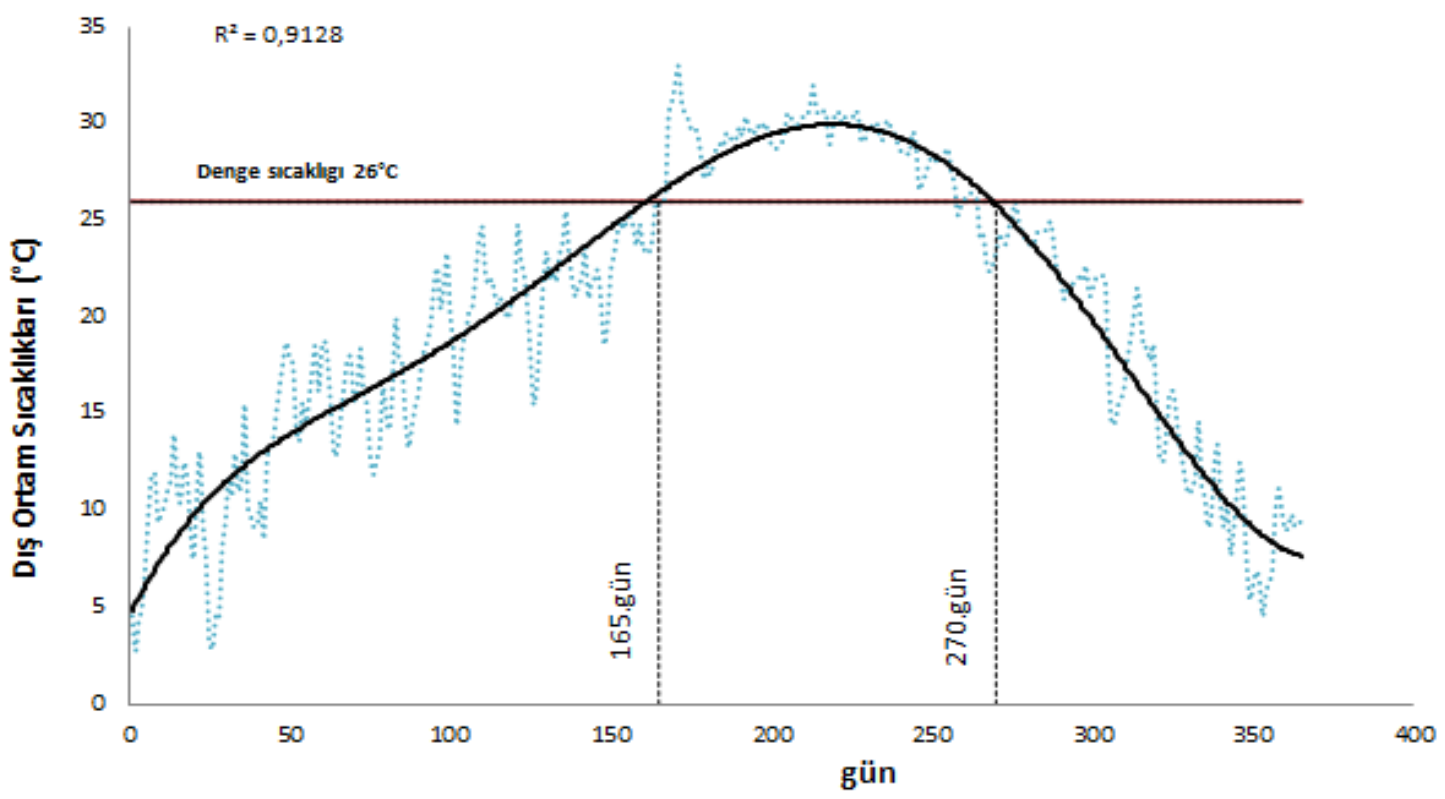

Şekil 3. Adana ili için dış hava sıcaklığının yıl boyunca günlük değişimi $\left(\mathrm{T}_{\mathrm{i}}=26^{\circ} \mathrm{C}\right)$

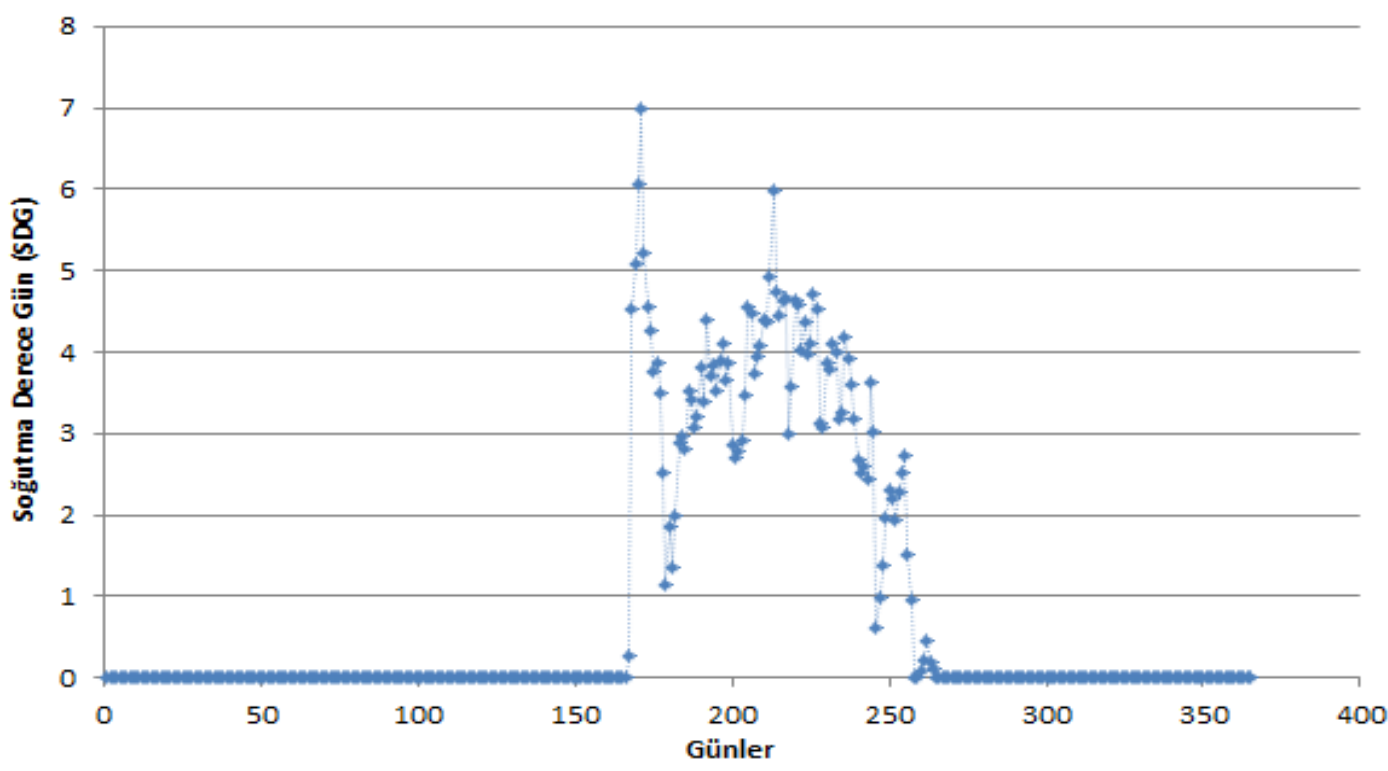

Şekil 4. Dış ortam sıcaklıklarına göre Soğutma Derece-Gün değerlerinin değişimi

Şekil 5 ve 7 ise güneș ışınımının da dikkate alındığı Adana ili için eșdeğer çevre sıcaklığının yıl boyunca değişimini sırasıyla 18 ve $26^{\circ} \mathrm{C}$ denge sıcaklıkları için göstermektedir. Bu şekiller eşdeğer çevre sıcaklığına bağlı olarak ısıtma ve sğutma yapılan günlerin belirlenmesi amacıyla çizilmiştir. Isıtma 17 Kasım'da başlayıp 24 Mart'a kadar yapılırken soğutma 1 Haziranda başlayıp 1 Ekimde sona ermiştir. Isıtmanın ve soğutmanın yapıldığı 1sıtma ve soğutma derece-gün değerleri ise Şekil 6 ve 8 'de verilmektedir. Güneş ışınımının da etkisiyle IDG $=753{ }^{\circ} \mathrm{C}$.gün ve $\mathrm{SDG}=410^{\circ} \mathrm{C}$.gün olarak belirlenmiştir. 


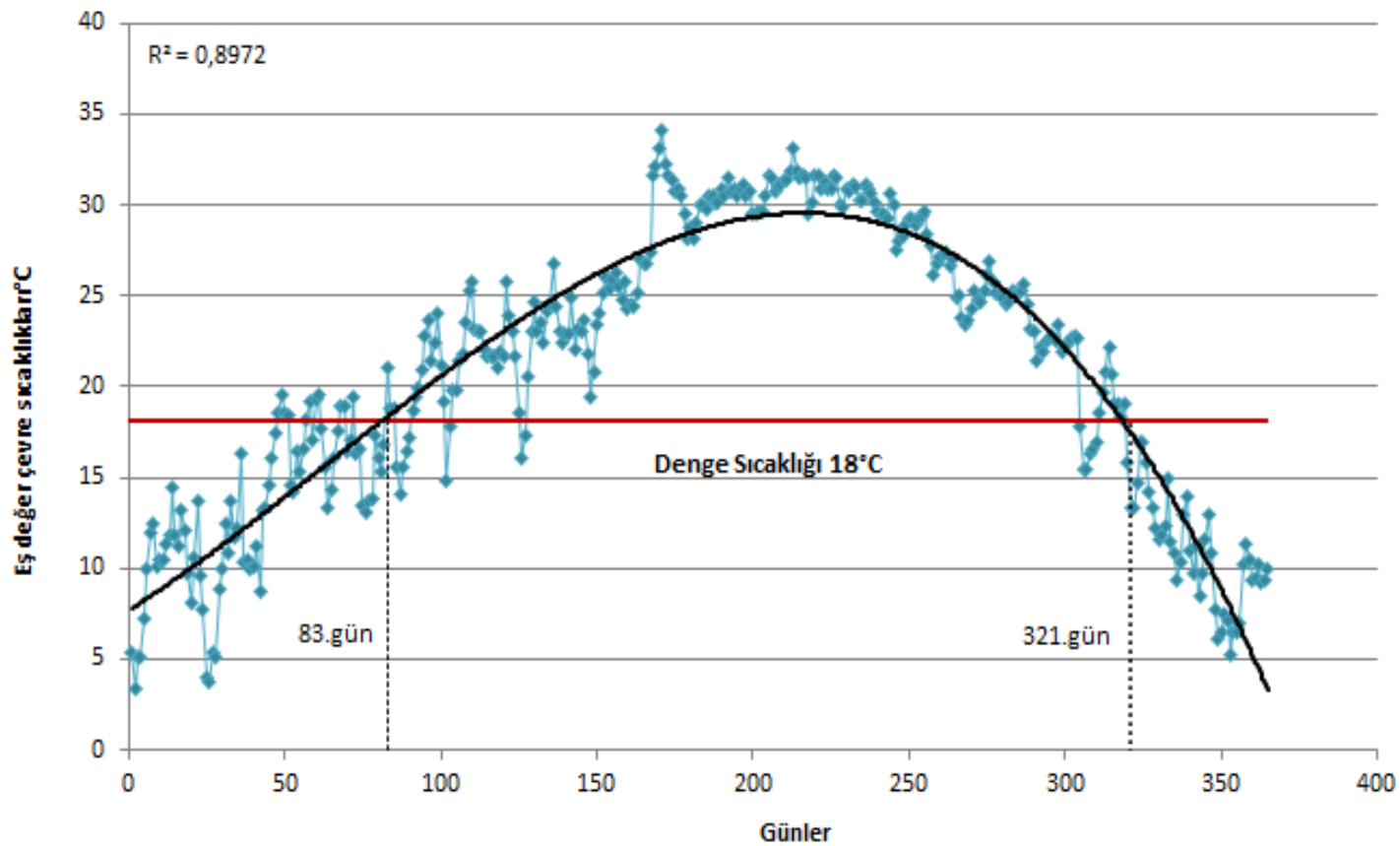

Şekil 5. Adana ili için eşdeğer çevre sıcaklığının yıl boyunca günlük değişimi $\left(\mathrm{T}_{\mathrm{i}}=18^{\circ} \mathrm{C}\right)$

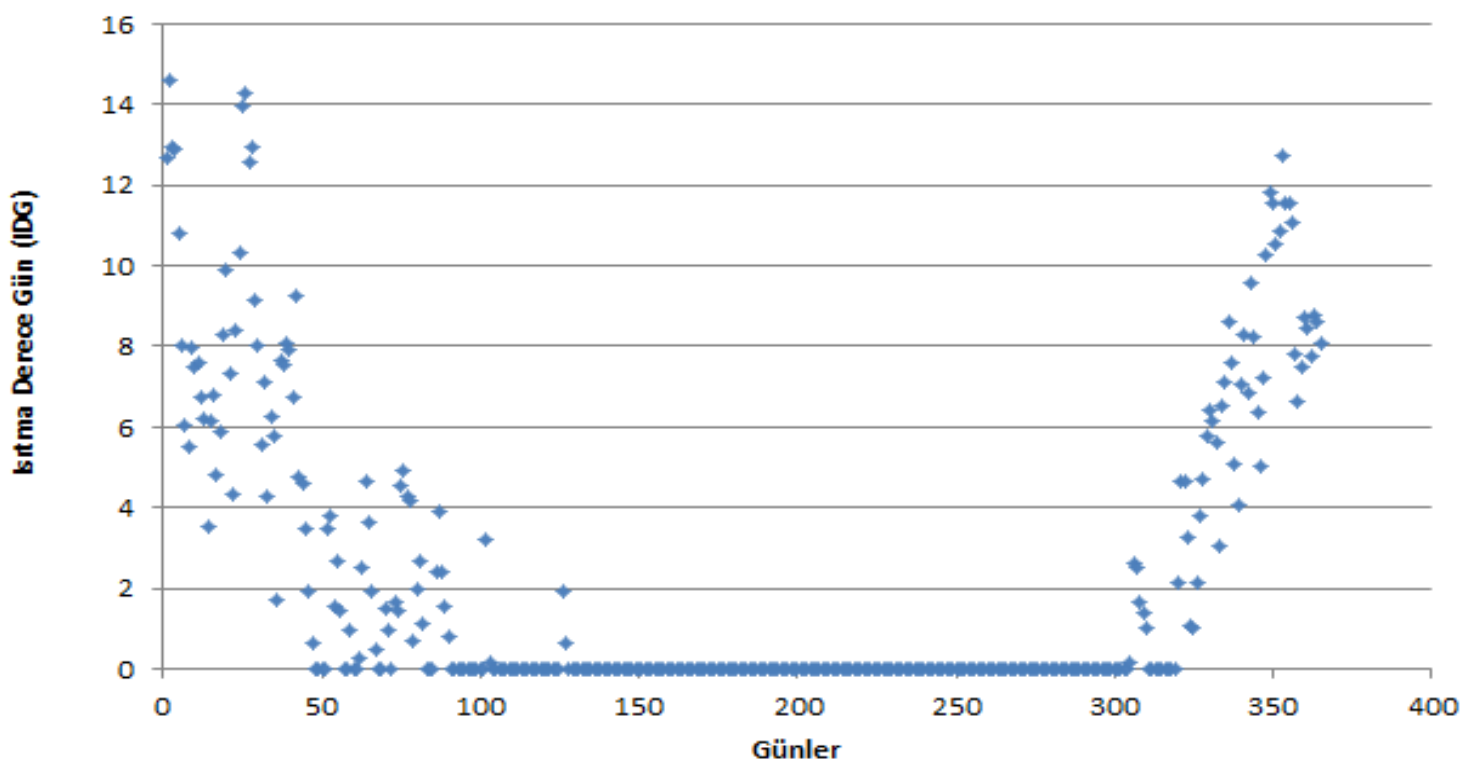

Şekil 6. Eşdeğer çevre sıcaklıklarına göre Isıtma Derece-Gün (IDG) değerlerinin değişimi 
Dış Ortam Sıcaklıkları ve Güneş Işınımı Şiddeti Dikkate Alınarak Adana İli İçin Optimum Yalıtım Kalınlı̆̆ı Tespiti

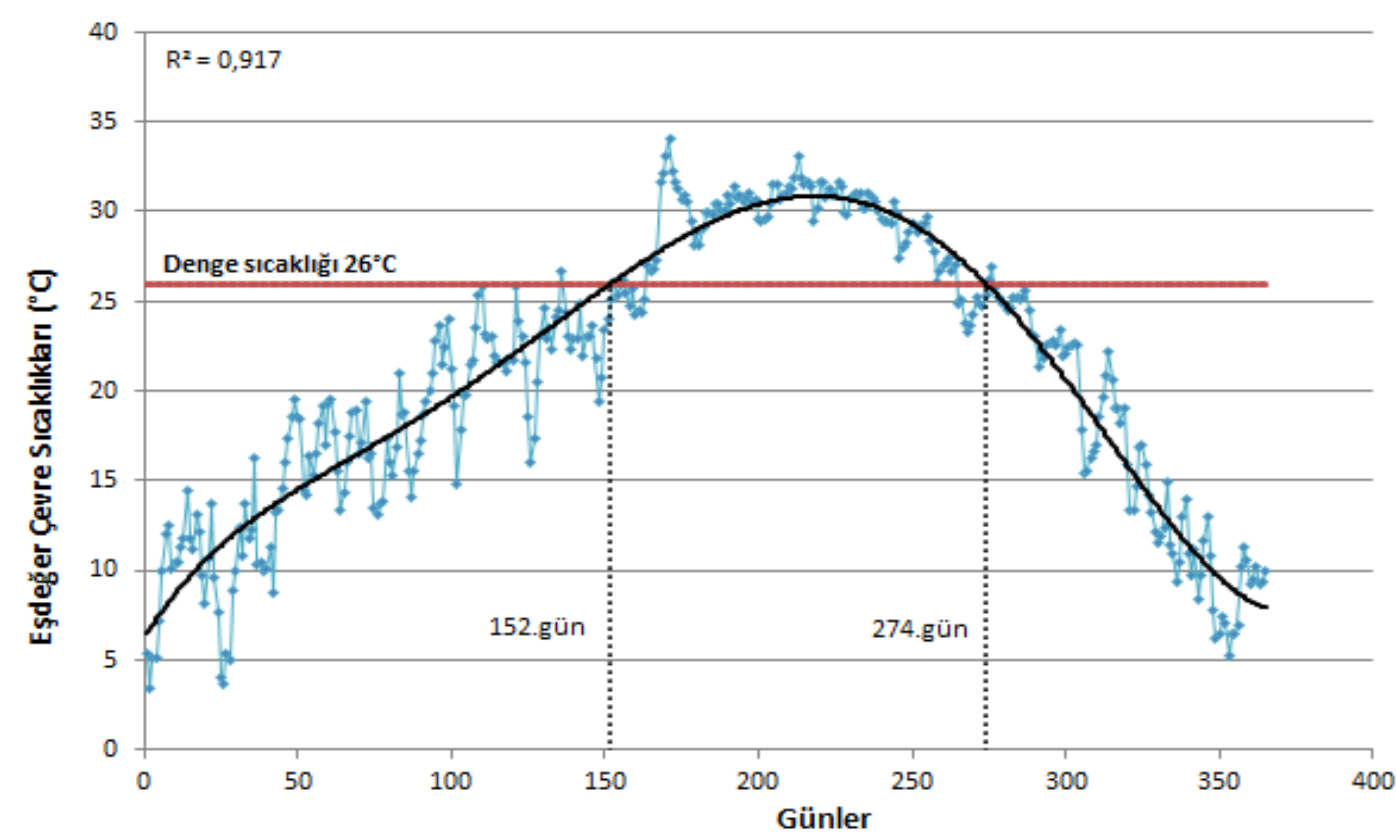

Şekil 7. Adana ili için eşdeğer çevre sıcaklığının yıl boyunca günlük değişimi $\left(\mathrm{T}_{\mathrm{i}}=26^{\circ} \mathrm{C}\right)$

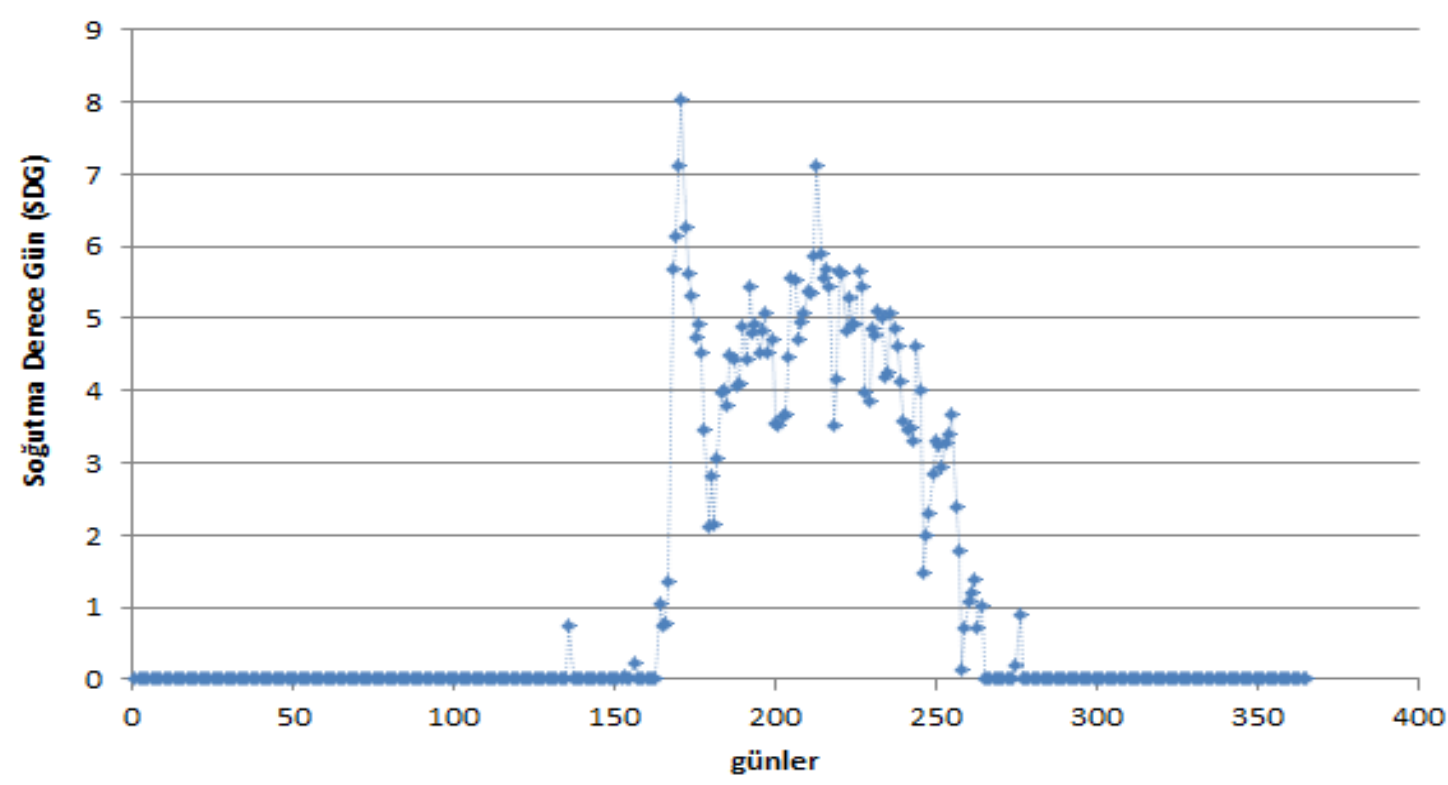

Şekil 8. Eşdeğer çevre sıcaklıklarına göre Soğutma Derece-Gün (SDG) değerlerinin değişimi

Adana ilinin 1sıtma ve soğutma periyotları ile Isıtma ve Soğutma Derece Gün değerleri, sadece dış ortam sıcaklık verileri kullanılarak ve güneş ışınımı değerlerinin de dikkate alındığı eşdeğer çevre sıcaklığına göre Tablo 2 ve 3' de ayrıca gösterilmiştir. Güneş ışınımı dikkate alınmadığında 4 Kasım-1 Nisan arasında 1sıtma yapılması gerekirken güneş 1şınımı dikkate alındığında 17 Kasım-24 Mart arasında 1sıtma yapılması gerektiği görülmektedir. Yine güneş 1şınımı dikkate alınmadığında 14 Haziran-27 Eylül arasında soğutma yapılması gerekirken güneş ışınımı dikkate alındığında 1 Haziran-1 Ekim arasında soğutma yapılması gerektiği görülmektedir. Görüldüğü gibi güneş ışınımının dikkate alınmasıyla 1sıtma yapılan gün sayısı ve dolayısıyla IDG değeri azalırken soğutma periyodu ve SDG değeri artmıştır. Bu değerler daha sonra optimum yalıtım kalınlığının belirlenmesi için maliyet analizi hesaplamalarında kullanılmıştır. 
Tablo 2. Dış ortam sıcaklığına ve Eşdeğer çevre sıcaklığına göre 1sıtma ve soğutma periyotlarının tespiti

\begin{tabular}{|c|c|c|c|c|c|c|}
\hline Durum & \multicolumn{3}{|c|}{ ISITMA PERIYODU } & \multicolumn{3}{c|}{ SOĞUTMA PERIYODU } \\
\hline $\begin{array}{c}\text { Güneş } \\
\text { 1şınımı } \\
\text { ihmal }\end{array}$ & $\begin{array}{c}\text { Denge } \\
\text { s1caklığ }\end{array}$ & Başlangıç Günü & Bitiş Günü & $\begin{array}{c}\text { Denge } \\
\text { sicaklığ } 1\end{array}$ & Başlangıç Günü & Bitiş Günü \\
\cline { 2 - 7 } & $18^{\circ} \mathrm{C}$ & 308. gün (4 Kasım) & 91. gün (1 Nisan) & $26^{\circ} \mathrm{C}$ & 165. gün (14 Haziran) & 270. gün (27 Eylül) \\
\hline $\begin{array}{c}\text { Güneş } \\
\text { 1şınımı } \\
\text { varken }\end{array}$ & $\begin{array}{c}\text { Denge } \\
\text { sicaklığ }\end{array}$ & Başlangıç Günü & Bitiş Günü & $\begin{array}{c}\text { Denge } \\
\text { sicaklığ1 }\end{array}$ & Başlangıç Günü & Bitiş Günü \\
\cline { 2 - 7 } & $18^{\circ} \mathrm{C}$ & 321 gün (17 Kasım) & 83. gün (24 Mart) & $26^{\circ} \mathrm{C}$ & 152. gün (1 Haziran) & 274. gün (1 Ekim) \\
\hline
\end{tabular}

Tablo 3. Denge sıcaklıklarına göre belirlenen Derece-Gün Sayıları ( ${ }^{\circ} \mathrm{C}$.gün)

\begin{tabular}{|c|c|c|}
\hline $\begin{array}{c}\text { Derece } \\
\text { Gün } \\
\text { Değerleri }\end{array}$ & $\begin{array}{c}\text { Güneş } \\
\text { 1şınımı ihmal }\end{array}$ & $\begin{array}{c}\text { Güneş } \\
\text { 1şınımı } \\
\text { varken }\end{array}$ \\
\hline IDG & 838 & 753 \\
\hline SDG & 315 & 410 \\
\hline
\end{tabular}

Adana ili için elde edilen IDG ve SDG değerleri daha sonra optimum yalıtım kalınlığının belirlenmesi için maliyet analizi hesaplamalarında kullanılmıştır. Şekil $9(a-b)$ ve $10(a-b)$ güneş 1şınımı yokken ve dikkate alındığında sırasıyla EPS ve XPS yalıtım malzemeleri için yalıtım kalınlığına göre maliyetlerin değişimini göstermektedir. Şekillerden görüldüğü gibi artan yalıtım kalınlığı ile yakıt maliyeti azalırken yalıtım maliyeti ise lineer olarak artmaktadır. Toplam maliyet ise belirli bir değere kadar azalmakta ve bu değerden sonra artmaktadır. Dolayısıyla toplam maliyetin minimum olduğu değer optimum yalıtım kalınlığını vermektedir. Bu durumda EPS ve XPS yalıtım malzemeleri için optimum yalıtım kalınlıkları güneş ışınımı dikkate alınmadan sırasıyla 7.6 ve $4.7 \mathrm{~cm}$ olarak elde edilmiştir. Maliyet analizi güneş 1şınımının dikkate alındığ durum içinde yapılmış ve güneş 1şınımının etkisiyle optimum yalıtım kalınlıklarının EPS ve XPS yalıtım malzemeleri için sırasıyla 8.0 ve $4.8 \mathrm{~cm}$ olarak elde edildiği görülmüştür. Bu çalışmada elde edilen sonuçlar Adana ili için yalıtım kalınlığının seçiminde önemli olacaktır.

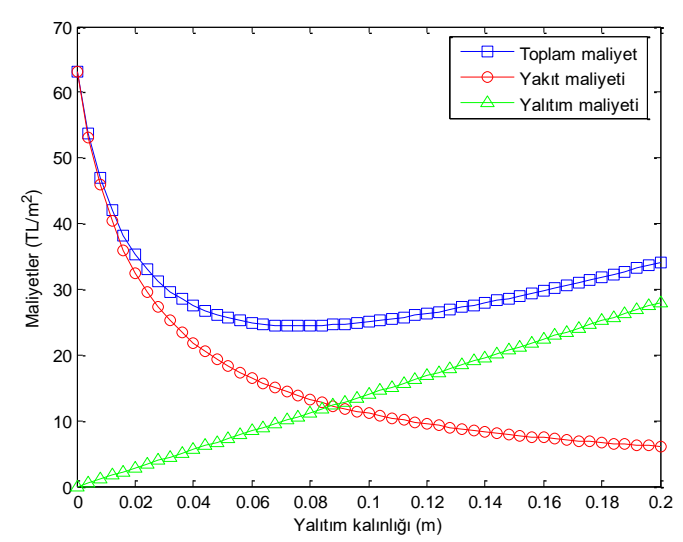

(a)

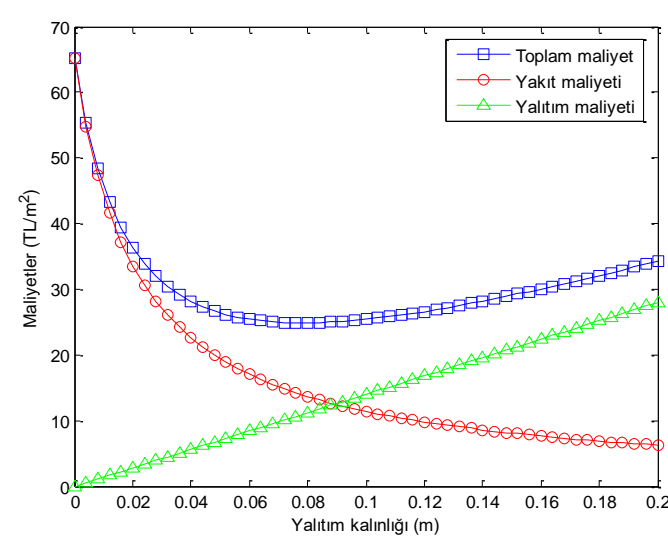

(b)

Şekil 9. EPS yalıtım malzemesi için yalıtım kalınlığına göre maliyetlerin değişimi a) Güneş ışınımı yokken b) Güneş 1şınımı dikkate alındığında 


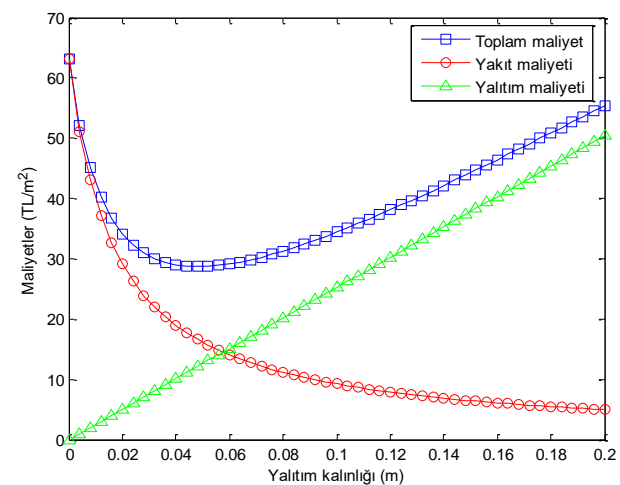

(a)

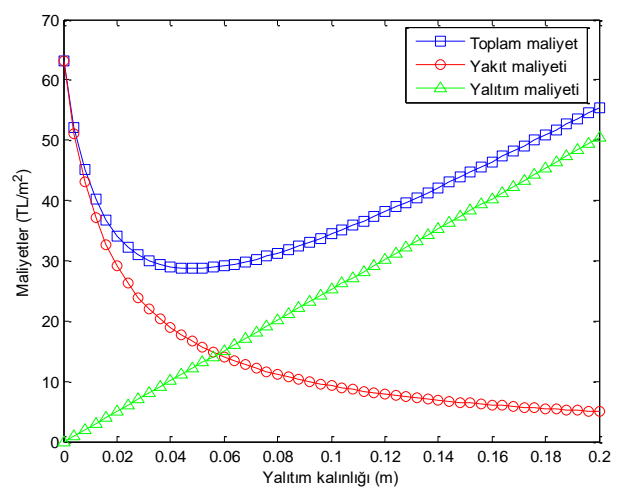

(b)

Şekil 10. XPS yalıtım malzemesi için yalıtım kalınlığına göre maliyetlerin değişimi a) Güneş ışınımı yokken b) Güneş ışınımı dikkate alındığında

\section{Kaynaklar}

[1] Dağıdır C, Bolattürk A. Sıcak İklim Bölgelerindeki Binalarda Isıtma ve Soğutma Yüküne Göre Tespit Edilen Optimum Yalıtım Kalınlıklarının Karşılaştırılması. Tesisat Mühendisliği Dergisi 2011; 17 (124): 64-77.

[2] Özel M. Dört Farklı İl İçin Optimum Yalıtım Kalınlıklarının Belirlenmesi ve Çevresel Analiz. Makine Teknolojileri Elektronik Dergisi 2013; 10(1): 1-17

[3] Yıldız A, Gürlek G, Erkek M, Özbalta N. Economical and Environmental Analyses of Thermal Insulation Thickness in Buildings. Is1 Bilimi ve Tekniği Dergisi 2008; 28(2): 25-34.

[4] Kaynakli O. A Study on Residential Heating Energy Requirement and Optimum Insulation Thickness. Renewable Energy 2008; 33: 1164-1172.

[5] Özel M, Şengür S. Farklı Yakıt Türü ve Yalıtım Malzemelerine Göre Optimum Yalıtım Kalınlığının Belirlenmesi. Tesisat Mühendisliği Dergisi 2013; 6-11.

[6] Çomaklı K, Yüksel B. Optimum Insulation Thickness of External Walls for Energy Saving. Applied Thermal Engineering 2003; 23: 473-479.

[7] Gölcü M, Dombaycı ÖA, Abalı S, Denizli için Optimum Yalıtım Kalınlığının Enerji Tasarrufuna Etkisi ve Sonuçları. Gazi Üniv. Müh. Mim. Fak. Dergisi 2006; 21(4): 639-644.

[8] Hasan A. Optimizing Insulation Thickness for Buildings using Life Cycle Cost. Applied Energy 1999; 63: 115-124.

[9] Bolattürk A. Binalarda Optimum Yalıtım Kalınlıklarının Hesabı ve Enerji Tasarrufundaki Rolü. 14. Ulusal Isı Bilimi ve Tekniği Kongresi 2003; 41-47.

[10] Bolattürk A. Determination of Optimum Insulation Thickness for Building Walls With Respect to Various Fuels and Climate Zones in Turkey. Applied Thermal Engineering 2006; 26: 1301-1309.

[11] Dombaycı ÖA, Gölcü M, Pancar Y. Optimization of insulation thickness for external walls for different energy-sources, Applied Energy 2006; 83: 921-928.

[12] Bolattürk A. Optimum insulation thicknesses for building walls with respect to cooling and heating degreehours in the warmest zone of Turkey, Building and Environment 43 (2008) 1055-1064.

[13] Yu J, Yang C, Tian L, Liao D. A study on optimum insulation thicknesses of external walls in hot summer and cold winter zone of China, Applied Energy 2009; 86: 2520-2529.

[14] Al-Khawaja MJ. Determination and selecting the optimum thickness of insulation for buildings in hot countries by accounting for solar radiation, Appl Therm Eng 2004;24:2601-10.

[15] Daouas N. A study on optimum insulation thickness in walls and energy savings in Tunisian buildings based on analytical calculation of cooling and heating transmission loads, Applied Energy 2011; 88: 156-164.

[16] Al-Sanea SA, Zedan MF, Al-Ajlan SA. Heat transfer characteristics and optimum insulation thickness for cavity walls, J. Therm. Env. Bldg. Sci. 2003; 26: 285-307.

[17] Al-Sanea SA, Zedan MF, Al-Ajlan SA. Effect of electricity tariff on the optimum insulation-thickness in building walls as determined by a dynamic heat-transfer model, Applied Energy 2005; 82: 313-330.

[18] Ozel M, Pıhtılı K. Isıtma ve soğutma derece gün değerlerini kullanarak optimum yalıtım kalınlığının belirlenmesi. Sigma Mühendislik ve Fen Bilimleri Dergisi 2008; 26(3): 191-198. 
[19] Kaynakli O, Özdemir S, Karamangil Mİ. Güneş Işınımı ve Duvar Yönü Dikkate Alınarak Optimum Isıl Yalıtım Kalınlığının Belirlenmesi. Gazi Üniv. Müh. Mim. Fak. Der. 2012; 27(2): 367-374.

[20] Yamankaradeniz R, Kaynaklı Ö. Isıtma Süreci ve Optimum Yalıtım Kalınlığı Hesabı. VIII. Ulusal Tesisat Mühendisleri Kongresi 2007; İzmir, 187-195.

[21] Bolattürk A. Optimum Insulation Thicknesses for Building Walls with Respect to Cooling and Heating Degree-Hours in the Warmest Zone of Turkey. Building and Environment 2008; 43: 1055-1064.

[22] Özel M, Tunç D. Kars İlindeki Binalar İçin Isıtma Yükü ve Optimum Yalıtım Kalınlığının Belirlenmesi. Firat Üniversitesi Mühendislik Bilimleri Dergisi 2018; 30 (1): 251-257.

[23] Threlkeld, JL. Thermal Environmental Engineering. Prentice-Hall, Englewood Cliffs, NJ, 1998.

[24] IZOCAM fiyat listesi.

[25] http://www.dosider.org. 